\title{
Chapter II.6
}

\section{SOME EXAMPLES OF GYPSUM KARSTS AND THE MORE IMPORTANT GYPSUM CAVES IN SPAIN Jose Maria Calaforra \& Antonio Pulido-Bosch}

\begin{abstract}
Spain possesses some of the most important examples of gypsum karst in Europe, in terms of the extent and variety of the gypsiferous outcrops. These are divided into gypsum belonging to the Triassic, Palaeogene and Neogene epochs, each of which displays different lithological and structural aspects. Some of Spain's most significant gypsum karsts, from the speleological standpoint, are described, and these share a common characteristic of all supporting the development of large caves. Reference is made to the geomorphology, hydrogeology and hydrochemistry of the gypsum karsts of Sorbas, Vallada and Gobantes-Meliones, which provide significant examples of intrastratal karst, speleogenesis by saline groundwater mixing and the influence of carbonate strata, respectively. Finally, brief geomorphological and speleogenetic descriptions of the more significant gypsum caves in Spain are given, together with a list of the longest and deepest gypsum caves in Spain.
\end{abstract}

\section{Introduction}

Spain contains some of the most extensive gypsum deposits in Europe. Some $30,000 \mathrm{~km} 2$ of gypsum outcrop exists (Ayala et al, 1986), all of which is, in principle, susceptible to karstification. Not only is the area of such outcrops large, but there is also a great lithological and chronostratigraphical variety, with gypsum ranging from Triassic to Quaternary in age (Fig. 1). The most noteworthy outcrops, those most affected by karstification, are described briefly below.

Triassic gypsum. These deposits occur mainly to the Betic mountain range, though there are also significant outcrops in the Pyrenees and Iberian range. They are Keuper facies gypsum, with many clayey, sandy and carbonate intercalations. The group is intensely tectonized and is even affected by diapiric phenomena. Significant examples include the gypsum karsts at Baena (Córdoba; Calaforra and Pulido-Bosch, 1989), Fuente Camacho (Granada; Calaforra and PulidoBosch, 1989b), Estella-Allo (Navarra; Eraso, 1959), Gobantes-Meliones (Málaga; Calaforra, 1996a), Archidona (Málaga; Durán and Burillo, 1985), Antequera (Málaga; Molina, 1982), Caravaca (Murcia), Vallada (Valencia; Pulido-Bosch, 1978) and Villena (Alicante; Cuenca, 1970), among many others.

Palaeogene gypsum. These deposits are located to the north of the Ebro basin, close to the edge of the Pyrenees range. They present a great lithological variety, with massive gypsum, common levels of anhydrite and marly, carbonate and clay intercalations. Some significant outcrops 


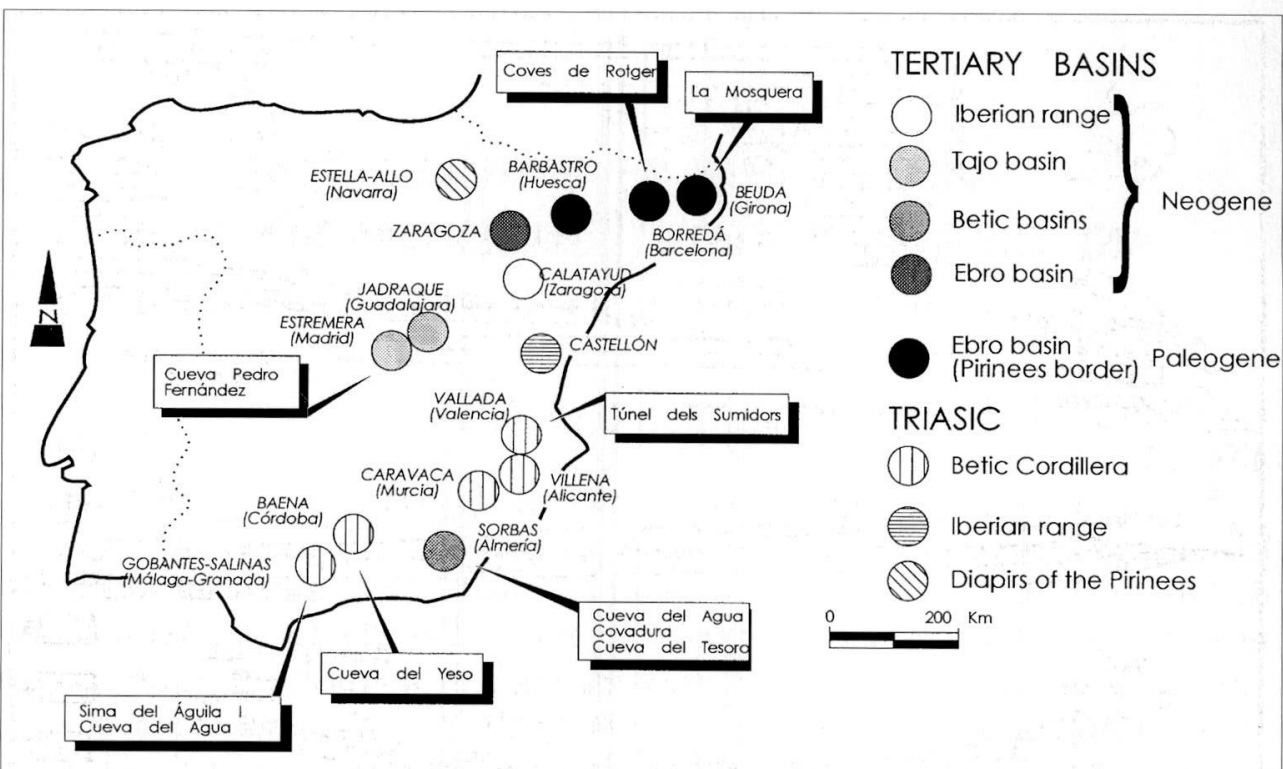

Fig. 1. Main karstic outcrops in gypsum, and the most important gypsum caves in Spain.

are those of Barbastro (Huesca; Gutiérrez et al, 1985), Beudá (Girona; Lloses and Robert, 1978) and Borredá (Barcelona; Noguera and Germain, 1985), and examples of gypsum karstification, such as the Banyoles lake (Girona; Sanz, 1985).

Neogene gypsum. These deposits occupy the greatest area, and represent an evaporitic sequence with abundant detrital intercalations and a great textural variety within the gypsum levels. They are limited to four principal locations: the Tajo basin, the Ebro basin and the Betic and Iberian Tertiary basins. The most noteworthy outcrops, with clear indications of karstification, are those of Estremera (Madrid; Eraso and Lario, 1988) and Jadraque (Guadalajara) in the Tajo basin (Durán et al, 1989), Zaragoza and its surroundings in the Ebro basin (Gutiérrez and Gutiérrez, 1995), Calatayud in the Iberian range (Gutiérrez, 1996) and the Sorbas basin in the Betic range (Pulido-Bosch and Calaforra, 1993).

\section{Some Spanish gypsum karsts}

The gypsum karsts that are described in greatest detail in this paper were chosen for their speleological interest. All the karsts hold caves that are significant, either because of their length, their depth or their particular mode of speleogenesis.

\subsection{The gypsum karst of Sorbas}

The gypsum karst of Sorbas, in the province of Almería (SE Spain), has an outcrop some $12 \mathrm{~km} 2$ in extent. It lies within a topographic depression bounded to the north by the Filabres mountains and to the south by those of Alhamilla and Cabrera. The region has a semi-arid climate, 


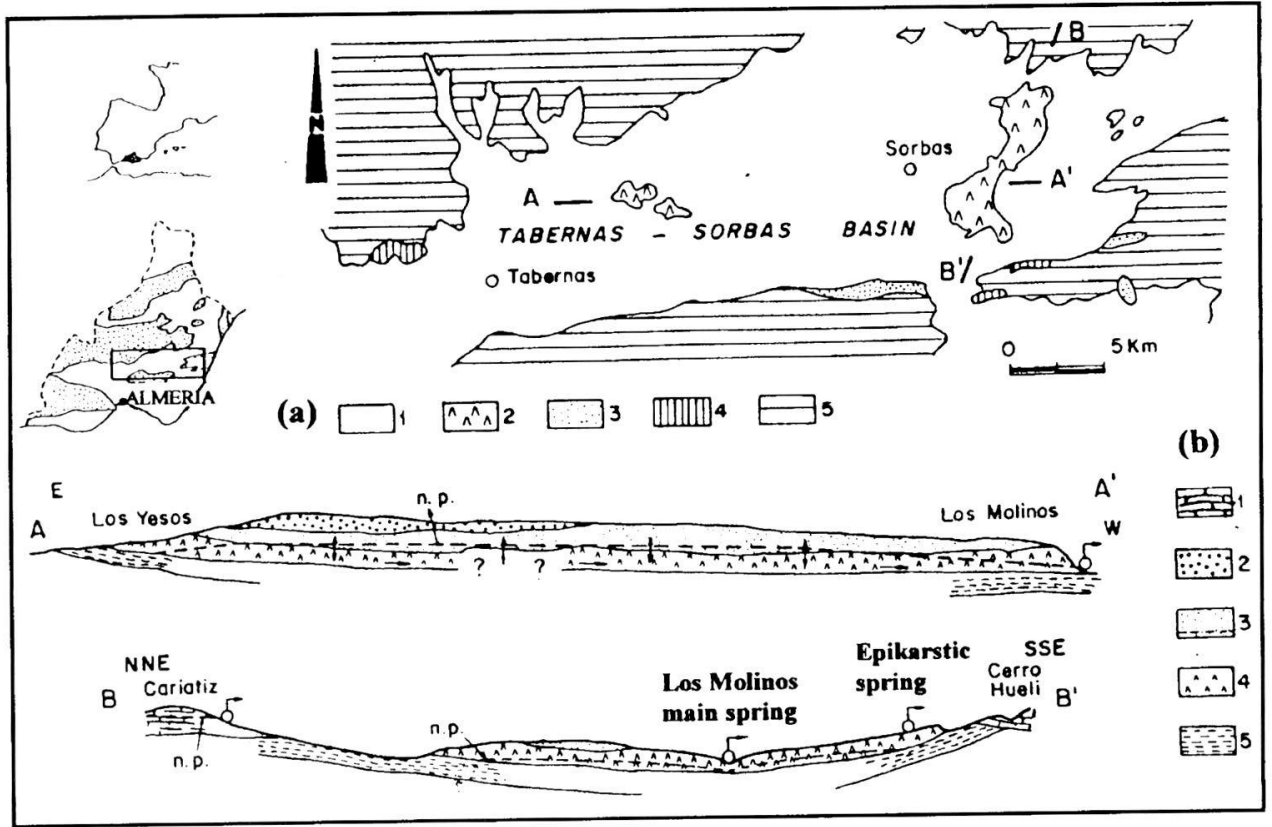

Fig. 2. Geological details of the gypsiferous outcrop of Tabernas-Sorbas (Almería) (after Calaforra \& PulidoBosch, 1997). Upper (a): 1- Neogene and Quaternary sediments (undifferentiated), 2-gypsum outcrops, 3-, 4- and 5-Betic units. Bottom (b): representative cross-sections, not to scale: 1- Reef limestone, 2- conglomerates (alluvial fans), 3-sandstones (coastal facies), 4-gypsum and interstratal marls, 5- silts (impervious base level), n.p.: piezometric level.

with a mean annual precipitation of less than $250 \mathrm{~mm}$. Mean annual temperatures are around $180 \mathrm{C}$ (Calaforra, 1985), but there are extreme contrasts between daily maximum and minimum temperatures during a large part of the year.

Geologically, the Sorbas karst, which lies within the Sorbas-Tabernas intra-montagne basin (Fig. 2), part of the Betic range, is developed within a cyclic sequence of intercalated gypsum and marly-pelitic materials; the whole sequence belongs to the Messinian Stage (Dronkert, 1977). The full succession has a thickness of about $120 \mathrm{~m}$, with gypsum intervals of up to $30 \mathrm{~m}$. Tectonically, the materials are only slightly folded, being almost horizontal, with a small degree of tilting caused by the presence of a syncline, with its limbs close to horizontal, that affects the gypsum. Fracturing and stratification, though hardly visible on the surface, commonly had a decisive role in guiding the linear development and the configuration of the levels in the caves (Calaforra et al, 1991).

The gypsum aquifer extends irregularly beneath the post-evaporitic materials, remaining semiconfined for much of its length (Pulido-Bosch and Calaforra, 1993). The main spring for the whole aquifer system (the spring at Los Molinos) has a mean flow of some $70 \mathrm{Ls}^{-1}$ (Pulido-Bosch, 1982) and calcium-sulphate chemistry, with SIgyp values ranging between -0.1 and 0.0 , and of -0.2 with respect to calcite (Calaforra and Pulido-Bosch, 1988). There is another group of springs, related directly to the drainage of specific caves, which present hydrochemical variations when compared 
to the principal drainage of the aquifer. These variations are manifested by lower contents of chloride, sodium and magnesium, enabling a clear hydrogeological distinction to be made between the two groups of springs (Pulido-Bosch and Calaforra, 1993).

Among the more significant geomorphological aspects is the great density of karst forms present (Pulido-Bosch and Calaforra, 1986). In an area of just $12 \mathrm{~km}^{2}$ almost 1,000 sinkholes have been identified (Calaforra and Pulido-Bosch, 1997) giving an idea of the intense surface erosion/dissolution that the area as undergone. Some of the karstic systems developed in this area have more than 20 entrances and galleries over $8 \mathrm{~km}$ long (Cueva del Agua system; Ayuso et $\mathrm{al}, 1991$ ) or depths exceeding $100 \mathrm{~m}$ (Covadura system). Another noteworthy aspect is the presence of all types of karren and microkarren, comparable, morphologically, with similar developments in carbonate rocks (Calaforra, 1996b). The karstic typology most frequently found in the caves in this area corresponds to a scheme of erosional intrastratal karst (Calaforra, 1996a).

Gypsum karst evolution in the region began with the development of proto-conduits within the gypsum levels under semi-confined, or even confined, conditions within a multi-layer aquifer (Calaforra, 1996a). This stage must have progressed while continental post-evaporitic materials were being deposited, which itself implies an initial levelling of the karstic surface by the action of Plio-Quaternary erosional scouring. Subsequently, following the lowering of the piezometric level and partial erosion of the post-evaporitic sediments, the outcropping gypsum suffered a marked degree of surface erosion. This erosion also affected the marly-pelitic interbeds that were intersected in the already formed caves, developing cave passages with triangular erosional cross-sections.

Environmental problems concerning the karst of Sorbas have arisen, related particularly to the difficulty of its conservation (Villalobos and Calaforra, 1992). The special characteristics of this karst were the justification for it being declared an officially protected site. Nevertheless, uncontrolled mining and extraction of the gypsum continue to threaten the uniqueness of the area.

\subsection{The gypsum karst of Gobantes-Meliones (Málaga)}

The karstic outcrop of Gobantes-Meliones lies in the province of Málaga (southern Spain) in the neighbourhood of the Guadalhorce reservoir. The sector described is bounded by the SubBetic ranges of Humilladero (to the north) and Valle-Torcal (to the south) and the rocks belong to the geological group termed the "Trías de Antequera". Precipitation in this area is considerably more than in the Sorbas area, with values exceeding $700 \mathrm{~mm}$ per year.

The karstified rocks overlie Triassic strata of Keuper facies. A high level of tectonic activity is indicated, as are the effects of diapiric behaviour (Fig. 3). The gypsum is commonly saccharoidal and microcrystalline; however, a whole range of materials are embedded in this, and they are, to a greater or lesser extent, allochthonous, giving the unit a unique breccia-like appearance. In fact, an olistostromic origin has been suggested for these materials, explaining the presence of rocks from other Subbetic units (Martín-Algarra, 1991). If this interpretation is accepted, the formation of this mega-breccia would have to be attributed to events during the Miocene epoch, as a product of the displacement of Triassic sediments during the movement of the Guadalquivir olistostrom. Morphologically the outcrop comprises two large sub-circular masses, each with a gypsife- 


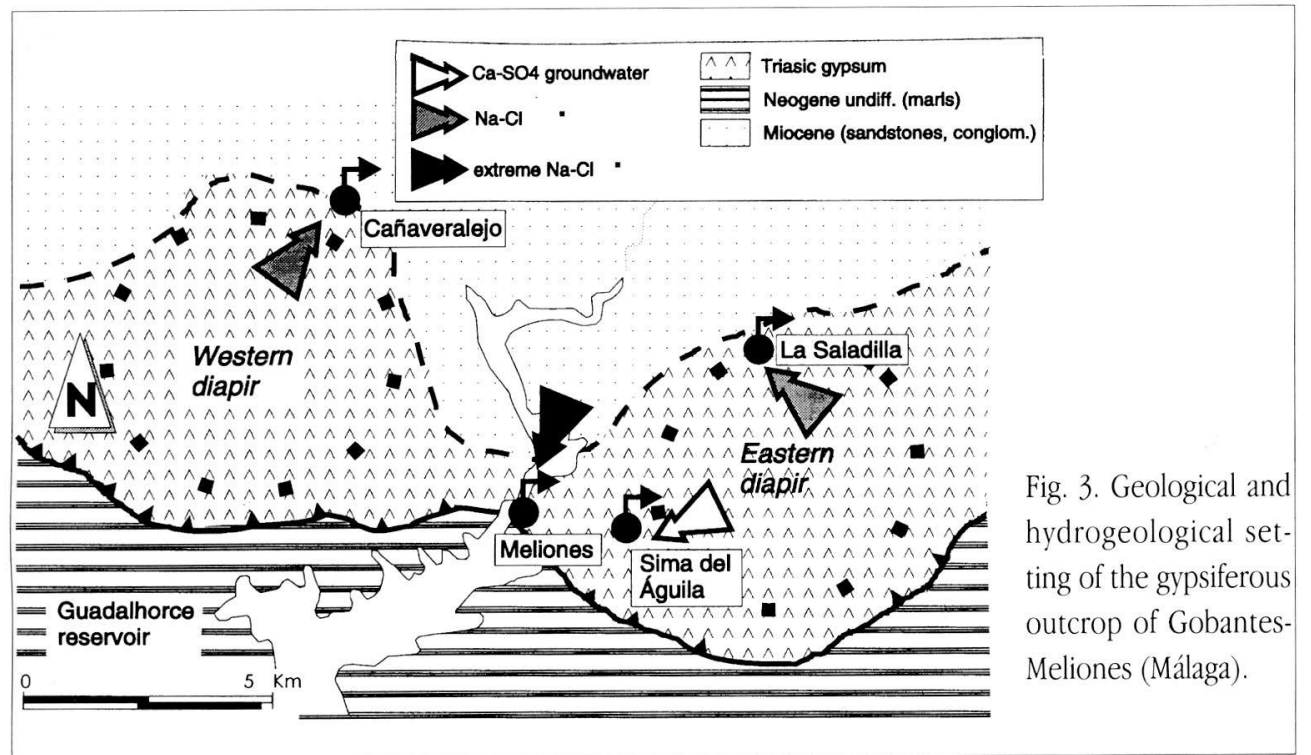

rous centre and sandstones, ophites and dolomites in the outer parts. This morphology and facies distribution might reflect the halo-kinetic behavior of these materials, a supposition that is supported by the existence of hyper-soluble salts at depth.

From the hydrogeological viewpoint, it is important to distinguish between the springs related to a highly saline deep flow (the Meliones and Cañaveralejo springs) and those springs with calcium sulphate chemistry, which drain only the Triassic gypsiferous beds (Carrasco and Benavente, 1986; Calaforra, 1996a). This duality is also found in other, nearby, karstified gypsum outcrops, such as that of Salinas-Fuente Camacho (Granada; Calaforra and Pulido-Bosch, 1993), which is also developed within a part of the "Trías de Antequera" group. The spring at Meliones, with a mean flow of some $10 \mathrm{Ls}^{-1}$, has a conductivity of over $200,000 \mathrm{mS} \mathrm{cm}^{-1}$ (Calaforra, op. cit.). This reflects a high groundwater salinity, around five times greater than the salinity of the Mediterranean, and gives some indication of the huge quantity of dissolved salts in its waters.

The caves that have been explored in this region are generally small, with notable exceptions, such as Sima del Aguila, with a depth of over $100 \mathrm{~m}$ or Cueva del Negro, with a length of over $1 \mathrm{~km}$ (Ramírez, 1995). These are frequently mixed caves, which have developed jointly within carbonate beds (boulders within the olistostromic breccia) and gypsiferousstrata.

Although the evolution of the gypsum karst of Gobantes-Meliones is currently governed by the apparently simple effect of dissolution upon the surface outcrop, various other factors may impinge upon this evolution and intensify the karstification process. One of these could be related to the halo-kinetic uprising of materials, which has enabled many of the caves to evolve in a vertical form, or to remain active above the base level at present occupied by the Guadalhorce river (Durán, 1984). A second potential process involves the phenomenon of hyper-karstification, resulting from the effect of salt water mixtures (Calaforra, 1996a), markedly intensifying gypsum dissolution, at least at depth. Finally, it has been noted that the processes of dolomitization and de- 


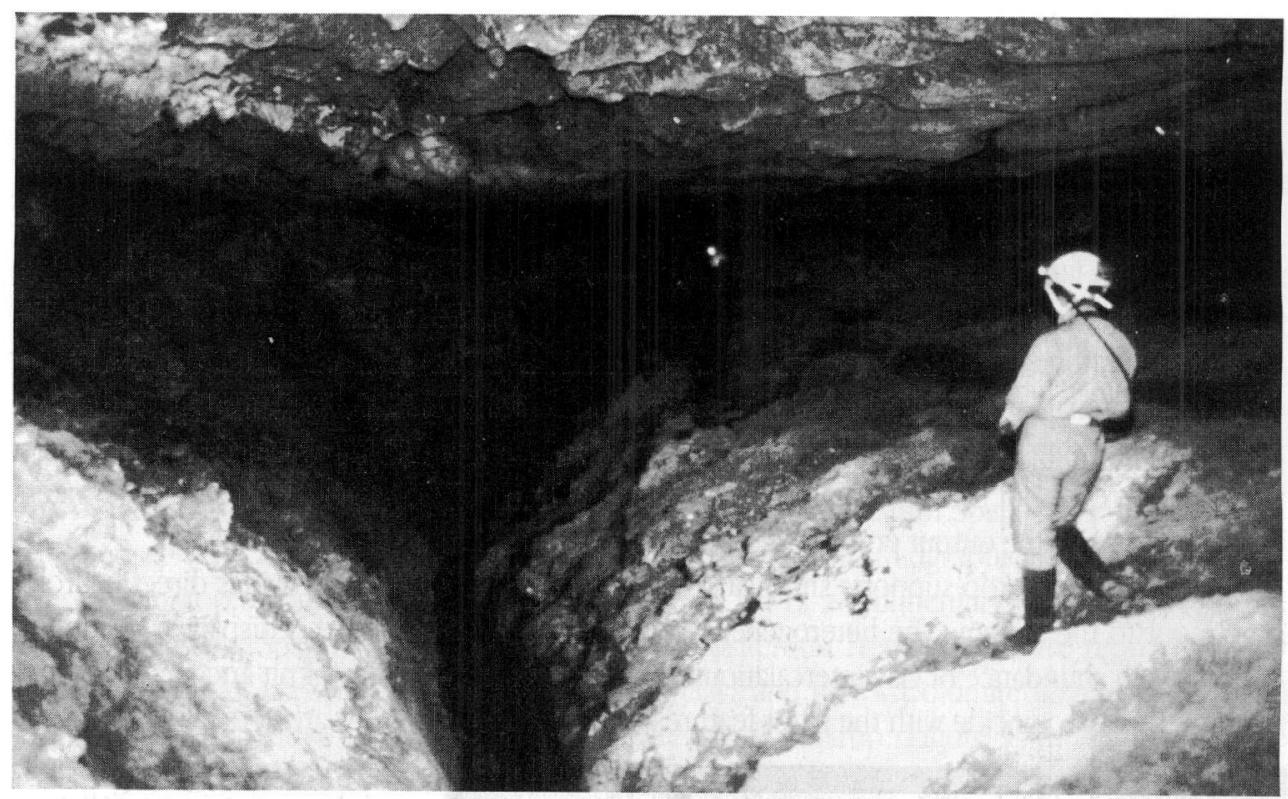

Plate 2. The Complejo GEP (gypsum karst of Sorbas, Spain). An intrastratal cave.

\section{The most significant gypsum caves in Spain}

This section describes the most notable or significant gypsum caves in Spain. It includes those of noteworthy length or depth, together with other examples that are significant because of the geological or hydrogeological surroundings in which they have developed.

\section{Cueva del Agua, $8350 \mathrm{~m}$ long (karst of Sorbas, Almería)}

This cave contains the most extensive gallery systems yet discovered in Spain (Baquero and Calaforra, 1994; Plate 1). It is located in the closed depression of the same name, in the northern part of the Sorbas gypsum outcrop. The basin forming its catchment is $1 \mathrm{~km}^{2}$ in area and includes almost 100 sinkholes, with diameters not exceeding 40m (Calaforra et al, 1991). It is currently being explored by the Almería Speleological Club (E.C.A.), and to date 24 different entrances to the system have been identified. A small watercourse runs through the cave; with a mean flow of less than $1 \mathrm{Ls}^{-1}$ (Calaforra et al, 1993), though in periods of heavy rainfall this may reach $1 \mathrm{~m}^{3} \mathrm{~s}^{-1}$ (Calaforra, 1996a). Two levels have been distinguished within the cave, separated by one of the marly intercalations that are characteristic of the gypsum sequence. The upper level features interstratification galleries and the lower one, frequently flooded, presents ancient and contemporary phreatic morphologies. 


\section{Covadura, $4245 \mathrm{~m}$ long (karst of Sorbas, Almería)}

This is the second longest and one of the deepest gypsum caves in Spain. It lies in the northern sector of the Sorbas gypsiferous outcrop, at a point where the evaporitic sequence is almost complete, and has not suffered any marked degree of erosion. The cave has developed across six different levels, each of which is located along the stratification planes between gypsiferous beds and marly intervals. The whole set of levels spans a vertical range of $126 \mathrm{~m}$, which is the approximate thickness of the gypsiferous succession. The cave originated under flooded conditions within a multi-layer aquifer, which subsequently evolved to become an erosive intrastratal karst (Plate 2; Calaforra, 1995).

\section{Cúeva de Pedro Fernández, 3204m long (karst of the Tajo river basin, Madrid)}

This is one of Spain's most important archeological caves, and hence access to the cave is currently restricted. It lies close to the town of Estremera, in the province of Madrid, and has developed in the Neogene evaporitic sediments of the Tajo basin. The main characteristic of the cave, differentiating it from other caves that have formed in Spain, is that it is a maze cave (Almendros and Antón, 1983), with a network of intersecting galleries that follow various lines of structural weakness (Eraso and Lario, 1988). The cave's origin reflects confined aquifer conditions, related to changes in water levels within the tributaries of the river Tajo (Calaforra, 1996a).

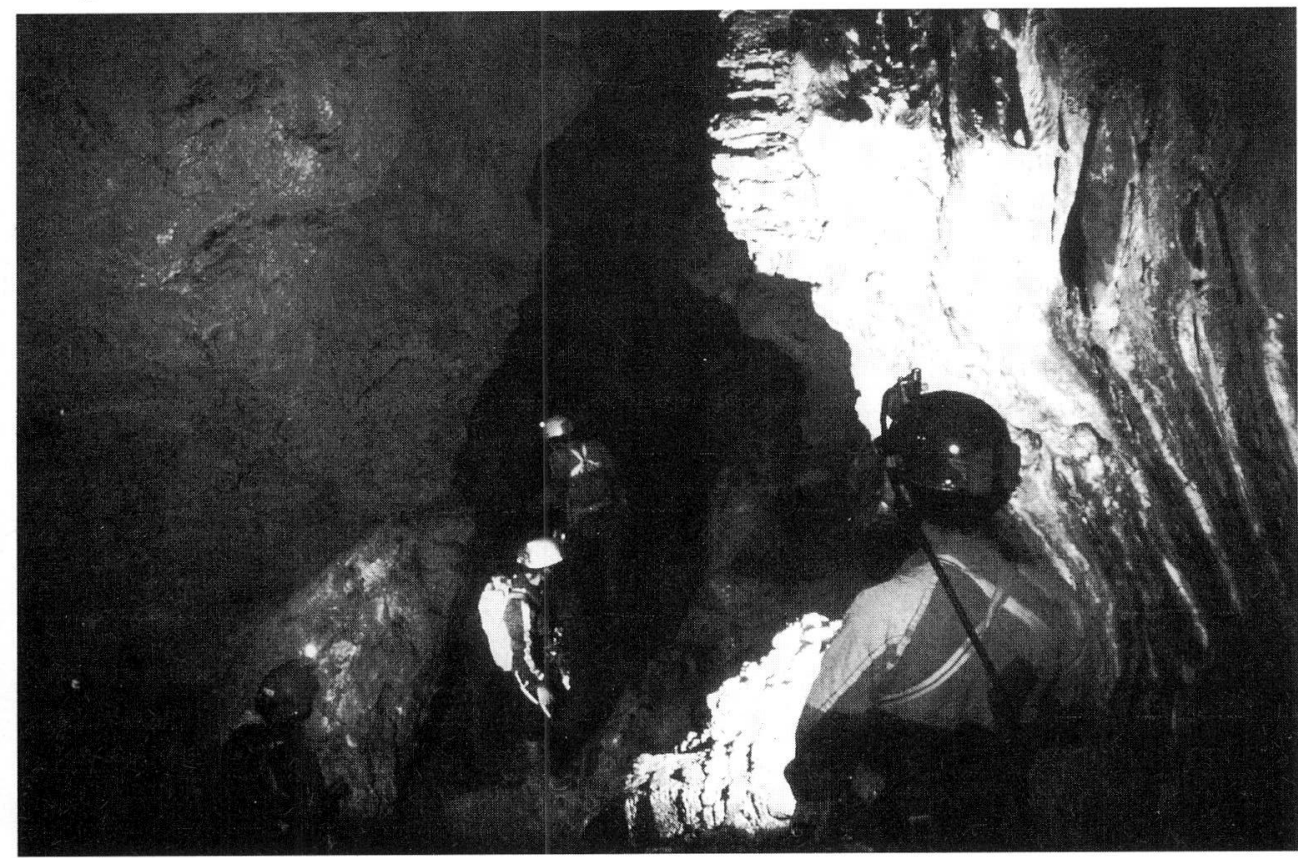

Plate 3. Tunel dels Sumidors (gypsum karst of Vallada), the deepest known gypsum cave in the world, showing an interbed of dolomite breccia in the cave. 


\section{Coves de Rotgers, $920 \mathrm{~m}$ long (karst of Borredá, Barcelona)}

This cave is special due to the characteristics of the materials in which it has is developed. These are marls and limestone with local interbeds of gypsum and anhydrite. The cave has very narrow passages and galleries that reach a depth of $79 \mathrm{~m}$ in one of the gypsum-anhydrite interbeds. The gypsum material displays the effects of changes produced by anhydrite hydration, a

\section{Longest gypsum caves of the Spain}

\begin{tabular}{|l|l|l|l|}
\hline Cave & Town & Province & Length \\
\hline 1. Cueva de Agua system & Sorbas & Almería & $8350 \mathrm{~m}$ \\
\hline 2. Covadura & Sorbas & Almería & $4245 \mathrm{~m}$ \\
\hline 3. Pedro Fernández cave & Estremera & Madrid & $3204 \mathrm{~m}$ \\
\hline 4. Cueva del Tesoro & Sorbas & Almería & $1890 \mathrm{~m}$ \\
\hline 5. Cueva del yeso & Baena & Córdoba & $1843 \mathrm{~m}$ \\
\hline 6. Sistema del Peral & Sorbas & Almería & $1800 \mathrm{~m}$ \\
\hline 7. Cueva de los Apas & Sorbas & Almería & $1500 \mathrm{~m}$ \\
\hline 8. Cueva del Negro & Antequera & Málaga & $1236 \mathrm{~m}$ \\
\hline 9. Túnel dels Sumidors & Vallada & Valencia & $1232 \mathrm{~m}$ \\
\hline 10. Cueva de los Ruidos & Sorbas & Almería & $1117 \mathrm{~m}$ \\
\hline
\end{tabular}

The deepest gypsum caves of the Spain

\begin{tabular}{|l|l|l|l|}
\hline Cave & Town & Province & Depth \\
\hline 1. Túnel dels Sumidors & Vallada & Valencia & $210 \mathrm{~m}$ \\
\hline 2. Sima del Corral & Sorbas & Almería & $130 \mathrm{~m}$ \\
\hline 3. Covadura & Sorbas & Almería & $126 \mathrm{~m}$ \\
\hline 4. Sima del Campamento & Sorbas & Almería & $122 \mathrm{~m}$ \\
\hline 5. Sima del Aguila & Antequera & Málaga & $112 \mathrm{~m}$ \\
\hline 6. Sima del Plástico & Sorbas & Almería & $96 \mathrm{~m}$ \\
\hline 7. Sima del Yoyo & Sorbas & Almería & $95 \mathrm{~m}$ \\
\hline 8. Cueva del Lapo & Sorbas & Almería & $94 \mathrm{~m}$ \\
\hline 9. Cueva de los Ruidos & Sorbas & Almería & $80 \mathrm{~m}$ \\
\hline 10. Coves de Rotgers & Borredá & Barcelona & $79 \mathrm{~m}$ \\
\hline
\end{tabular}

process that drove one of the first phases in the development of the cave.

\section{Tunel dels Sumidors, 210m deep (karst of Vallada, Valencia)}

This is the deepest known gypsum cave in the world (Calaforra et al, 1986). The principal gallery (Plate 3 ) has many passages that are almost horizontal. It is interrupted by abrupt projections, and pits up to $20 \mathrm{~m}$ deep, coinciding with vertical fractures and dolomitic interbeds. These are especially common in the final part of the gallery. A watercourse with a mean flow of about $5 \mathrm{Ls}^{-1}$ runs through the whole length of the cave, and is derived from the infiltration of small springs at 
the watershed. The cave ends at a siphon that is connected hydrologically to the saline spring of Saraella. Complete exploration of the siphon has not yet been possible.

\section{Sima del Aguila, 112m deep (karst of Gobantes-Meliones, Málaga)}

This is the most significant cave within the Gobantes karst and its ramifications are essentially vertical. Its initial part is developed along the contact between the gypsum and the Triassic limestone-dolomites, such that the pits follow the contact plane. At intermediate depth the cave collects infiltration waters from a small surface stream flowing over the gypsum. In its final part, the fissure reaches a massive bed of breccia with a microcrystalline gypsiferous matrix, forming a large chamber $30-40 \mathrm{~m}$ high with an area exceeding $200 \mathrm{~m}^{2}$, formed in response to the sudden lithological change and associated gravi-clastic processes.

\section{Large gypsum caves in Spain}

Finally, a revised catalogue is provided of the largest gypsum caves in Spain, classified both by length and depth. Note that only two caves are not in the Betic mountain range and more than $60 \%$ of the total are located in the gypsum karst of Sorbas (Almería).

\section{Acknowledgements}

To the members of the "Espeleo-Club Almería" for their continued dedication to the study of gypsum karst. This work was carried out in the context of the projects AMB92-0211 AMB95-0493 financed by the CICYT.

\section{References}

ALMENDROS, M.A. \& ANTON, F.J. 1983. El complejo kárstico-yesífero subterráneo "Pedro Fernández". Cuad. do Lab. Xeologico de Laxe, 5. 333-341.

AYALA, F, RODRIGUEZ, J.M., DEL VAL, J., DURAN, J.J., PRIETO C. \& RUBIO J. 1986 Memoria del mapa del karst en España. IGME. 68.

AYUSO, I., CALAFORRA, J.M., GARCIA-SANCHEZ, J., SENEN, J. \& THIBAULT, A. 1991. Estado actual de las exploraciones en el karst en yeso de Sorbas (Almería). Espeleotemas, 1. 22-27.

BAQUERO, J.C. \& CALAFORRA, J.M. 1994. Sistema de la Cueva del Agua, Sorbas (Almería). Mundo Subterráneo (TIASA eds). 153-160.

CALAFORRA, J.M. 1985. Hidrogeología de los yesos karstificados de Sorbas. Inst. Estud. Almerienses. 152.

CALAFORRA, J.M. 1995. El sistema Covadura. Mundo Subterráneo. Tecno-Ambiente, 48. 1-8p.

CALAFORRA, J.M. 1996a. Contribución al conocimiento de la karstología de yesos. Tesis, Univ. Granada (unpub.). 350.

CALAFORRA, J.M. 1996b. Some examples of gypsum karren. Int. Symp. on Karren Landforms. Univ. Illes Balears, . 253-260.

CALAFORRA, J.M., DELL'AGLIO, A. \& FORTI, P. 1993. The role of condensation-corrosion in the 
development of gypsum karst: the case of the Cueva del Agua (Sorbas, Spain). XI Int. Congr. Speleol.. 63-66.

CALAFORRA, J.M., GARAY, P. \& GONZALEZ-RIOS, J.M. 1986. Observaciones sobre las topografías realizadas en el "Tunel del Sumidor" (Valencia). Primer desnivel mundial en yesos. Lapiaz, 15. 2227.

CALAFORRA, J.M. \& PULIDO BOSCH, A. 1993. The hydrogeochemistry and morphology of the Triassic gypsum in the Salinas-Fuente Camacho area (Granada). In Some spanish karstic aquifers (Pulido-Bosch, ed.). Univ. Granada. 67-83.

CALAFORRA, J.M. \& PULIDO-BOSCH, A. 1988. The geochemistry of some sulphate ground waters in relation with gypsum karst (Almería, South Eastern Spain). Int. Cong. Karst Hydrogeology and Karst Environment Protection. AIHS, vol. 2. 877-882.

CALAFORRA, J.M. \& PULIDO-BOSCH, A. 1989a. Principales sistemas kársticos en yeso de España. El Karst en España. Monografías. Soc. Esp. Geomorfología, 4. 277-294.

CALAFORRA, J.M. \& PULIDO-BOSCH, A. 1989b. Les gypses triassiques de Fuente Camacho et ses alentours. Reunion Franco-Espagnole sur les karst mediterranées, Univ. Sevilla. 67-82.

CALAFORRA, J.M. \& PULIDO-BOSCH, A. 1997. Peculiar landforms in the gypsum karst of Sorbas (Southeastern Spain). Carbonates and Evaporites, 12, 1. (submit).

CALAFORRA, J.M., PULIDO-BOSCH, A. \& SANCHEZ-MARTOS, F. 1991. Geomorfología y estructura del sector de la Cueva del Agua, karst en yeso de Sorbas (Almería). Espeleotemas, 1. 28-35.

CARRASCO, F. \& BENAVENTE, J. 1986. Estimación de la aportación salina del río Guadalhorce en el sector de Bobadilla-Gobantes (provincia de Málaga). II SIAGA. 273-278.

CEBRIAN, R. 1982. El río Subterráneo "Tunel dels Sumidors". Valencia Atracción, 564. 16-17.

CUENCA, A. 1970. La cueva del Pozo. Una cavidad en los yesos triásicos de Villena (Alicante). Geo y Biokarst, 26. 8-14.

DRONKERT, H. 1977. The evaporites of the Sorbas Basin. Instituto de Investigaciones Geológicas. Dip. Prov. Barcelona, 33. 55-76.

DURAN, J.J. 1984. Evolución geomorfológica del cañón del río Guadalhorce en el Trías de Antequera (Archidona, Málaga). Cuad. Inv. Geogr. Col. Univ. de la Rioja, 1 and 2. 42-55.

DURAN, J.J. \& BURILLO, F.J. 1985. Triassic gypsum karst of the Loma del Yesar (Archidona, Málaga, Southern Spain). Le Grotte d'Italia, XII. 237-246.

ERASO, A. 1959. Karst en yeso del diapiro de Estella. Munibe, 4. 201-230.

ERASO, A. \& LARIO, J. 1988. Aplicación del método de predicción de las direcciones principales de drenaje al karst en yeso de Estremera (Madrid). II Congr. Geol. de España, 2. 391-394.

GUTIERREZ, M., IBAÑEZ, M.J., PEÑA, J.L., RODRIGUEZ,J. \& SORIANO, M.A. 1985. Quelques exemples de karst sur gypse dans la dépresion del'Ebre. Karstologia, 6. 29-36.

GUTIERREZ, F. \& GUTIERREZ, M. 1995. Geomofology of the tertiary gypsum formations in the Ebro depression. Int. Symp. Soil in gypsum Lleida, Spain). 15-21.

GUTIERREZ, F. 1996. Gypsum karstification induced subsidence (Calatayud grabben, Iberian range). Geomorphology, 16. 277-293.

GUZMAN, J.L., GARCIA-LOPEZ, M. \& PEREZ-LOPEZ, A. 1995. Una nueva perspectiva sobre el abastecimiento de Málaga (Los manantiales salinos de Meliones). VI Simposio de Hidrogeología, XIX. 
$449-462$.

LLOSES, R. \& ROBERT, A. 1978. Cova de la Mosquera. But. Cent. Ex. Grácia, 376. 85-87.

MARTIN-ALGARRA, A. 1991. Informe sobre la geología de la región comprendida entre Bobadilla, Campillos, el embalse del Guadalhorce y la Sierra Chimenea. Comisaría de Aguas del Sur de España (unpub.) . 38.

MOLINA, J.A. 1982. Los karst en yesos de la provincia de Málaga. "Avance". S.E.M. de Málaga, 75 Aniv. . 95-112.

NOGUERA, M. \& GERMAIN, J. 1978. El sistema de Rotgers. Bol. S.I.S, 6.

ORTI-CABO, F. 1974. El keuper del Levante español. Estudios Geológicos, 30. 7-46.

PULIDO-BOSCH, A. 1978. El karst en yesos de Vallada (Valencia). Incidencia en la calidad química de las aguas. Cuad. Geol., Univ. Granada, 8 y 9 . 113-122.

PULIDO-BOSCH, A. 1982. Consideraciones hidrogeológicas sobre los yesos de Sorbas (Almería). Reunión Monográfica sobre el Karst de Larra . 257-274.

PULIDO-BOSCH, A. \& CALAFORRA, J.M. 1986. Formas kársticas en los yesos de Sorbas (Almería). Estudios sobre Geomorfología del Sur de España . 115-119.

PULIDO-BOSCH, A. \& CALAFORRA, J.M. 1993. The gypsum karstic aquifer of Sorbas (Almería). In Some spanish karstic aquifers. (Pulido-Bosch, de.) Univ. Granada, . 225-241.

RAMIREZ, F. 1995. Grandes cavidades en la provincia de Málaga. Espeleotemas, 5. 71-94.

SANZ, M. 1985. Estudi hidrogeológic de la conca de Banyoles-Garrotxa. Cuaderns del Centre d'Estudis Comarcals de Banyoles (1980-84). 171-250.

VILLALOBOS, M. \& CALAFORRA, J.M. 1992. El karst en yeso de Sorbas: propuesta de un Plan de Uso Público para un modelo territorial alternativo. Espeleotemas, 2. 3-8. 